\title{
CD43 expression in B cell lymphoma
}

\author{
J Treasure, A Lane, D B Jones, D H Wright
}

\begin{abstract}
Aims: To determine the expression of CD43 in frozen sections in a range of $B$ cell lymphomas.
\end{abstract}

Methods: The monoclonal antibody WR14, clustered provisionally in the Fourth Leucocyte Typing Workshop as a CD43 reagent, was investigated by epitope blocking studies on formalin fixed reactive lymph node tissue, using the established CD43 antibody MT1, to validate its use as a CD43 reagent. CD43 expression was studied in 131 immunophenotypically defined B cell lymphomas, including lymphocytic lymphoma (Lc, $n=13$ ), centrocytic lymphoma $(C c, n=14)$, and a range of follicle centre cell lymphomas (FCC) including centroblastic/centrocytic follicular $(\mathrm{CbCcF}$, $n=48)$, centroblastic diffuse $(C b D, n=39)$, centroblastic/centrocytic diffuse $(\mathrm{CbCcD}$, $n=4$ ), centroblastic follicular and diffuse ( $\mathrm{Cb} F \mathrm{FD}, \mathrm{n}=3$ ) and centroblastic/centrocytic follicular and diffuse (CbCc FD, $n=1)$. Nine lymphomas of mucosa associated lymphoid tissue (MALT) were also examined.

Results: Epitope blocking studies showed that WR14 is a CD43 reagent that binds to an epitope identical with or close to that recognised by MT1. Eleven of $13(84 \%)$ cases of Lc and 11 of $14(78 \%)$ cases of $\mathrm{Cc}$ expressed CD43; 87 of 95 (91\%) cases of FCC did not. All eight low grade lymphomas of MALT were negative. One high grade lymphoma, transformed from a low grade MALT lymphoma, was positive for CD43. The expression of CD43 by tumours of $B$ cell lineage was associated with the expression of CD5 ( $p<0.001$ ) although either antigen could occasionally be found in the absence of the other.

Conclusion: CD43 reagents can be used in conjunction with CD5 antibodies for the immunophenotypic discrimination of follicle centre cell lymphomas from nonfollicle centre cell lymphomas.

(f Clin Pathol 1992;45:1018-1022)

CD43(sialophorin/leukosialin/glycoprotein 115) is a heavily glycosylated protein normally expressed by $\mathrm{T}$ lymphocytes, natural killer cells, and most myeloid cells, with weak expression in epithelial and synovial cells, fibroblasts, and chondrocytes. ${ }^{1}$ In peripheral blood most B lymphocytes do not express $\mathrm{CD} 43,{ }^{2}$ but it seems to be expressed as a surface marker very early on in B cell ontogeny. ${ }^{1}$ Evidence obtained in vitro suggests that CD43 may be expressed on B cells after activation. ${ }^{3}$ CD43 expression has been documented in lymphocytic lymphoma of B cell origin and B-CLL. Stross et al have described CD43 expression in five of six paraffin embedded biopsy specimens from patients with CLL and lymphocytic lymphoma, and also in 11 of 15 blood smears from patients with B-CLL. ${ }^{4}$ This suggests that the expression of CD43 parallels, at least in part, the expression of CD5.

Some authors have observed CD43 expression in a proportion of $\mathrm{B}$ cell lymphomas in formalin fixed, paraffin wax processed tissues, but the results have varied greatly, with positivity ranging from $0 \%,{ }^{5}$ to $21 \%^{6}$ for follicle centre cell lymphomas and from $22 \%^{7}$ to $100 \%^{5}$ for CD5 positive neoplasms. Such variability may be attributable in part to the sensitivity of the antigen to fixation effects. To date, however, little information has been available concerning CD43 expression in frozen sections of $B$ cell lymphomas.

The monoclonal antibody WR14 has been used in our routine diagnostic B cell panel for five years. In the Fourth Leucocyte Typing Workshop WR14 was provisionally clustered as a CD43 reagent $^{1}$ and we have performed epitope blocking studies to provide confirmatory evidence of this.

We reviewed our accumulated data concerning expression of CD43, demonstrated by WR14 in frozen section immunohistochemistry, in a range of 131 confirmed $B$ cell lymphomas, and we now report the results in association with histological classification and previously determined immunophenotype.

\section{Methods}

Cases ( $n=131$ ) of immunophenotypically defined B cell lymphoma for which both paraffin wax processed material and frozen

Table 1 Monoclonal antibodies used *

\begin{tabular}{|c|c|c|}
\hline WR14 & CD43 & $\mathrm{T}$, some $\mathrm{B}$, myeloid, natural \\
\hline $\begin{array}{l}\text { WR17 } \\
\text { HD37 } \\
\text { SHCL-1 } \\
\text { OKT1 } \\
\text { RFAL-1 } \\
\text { E11 }\end{array}$ & $\begin{array}{l}\text { CD37 } \\
\text { CD19 } \\
\text { CD22 } \\
\text { CD5 } \\
\text { CD10 } \\
\text { CD35 }\end{array}$ & $\begin{array}{l}\text { pan } B^{8} \\
\text { pan } B^{\circ} \\
\text { pan } B^{10} \\
T+B-c e l l \text { subset } \\
\text { CALLA } \\
(C R 1, C 3 b \text { receptor }) \text { follicular } \\
\text { dendritic cells }\end{array}$ \\
\hline $\begin{array}{l}\text { UCHT-1 } \\
\text { OKT3 }\end{array}$ & $\begin{array}{l}\text { CD3 } \\
\text { CD3 }\end{array}$ & $\begin{array}{l}\text { Mature } \mathrm{T}^{14} \\
\text { Mature } \mathrm{T}^{11}\end{array}$ \\
\hline
\end{tabular}

* Together with immunoglobulin light and heavy chain antibodies. 


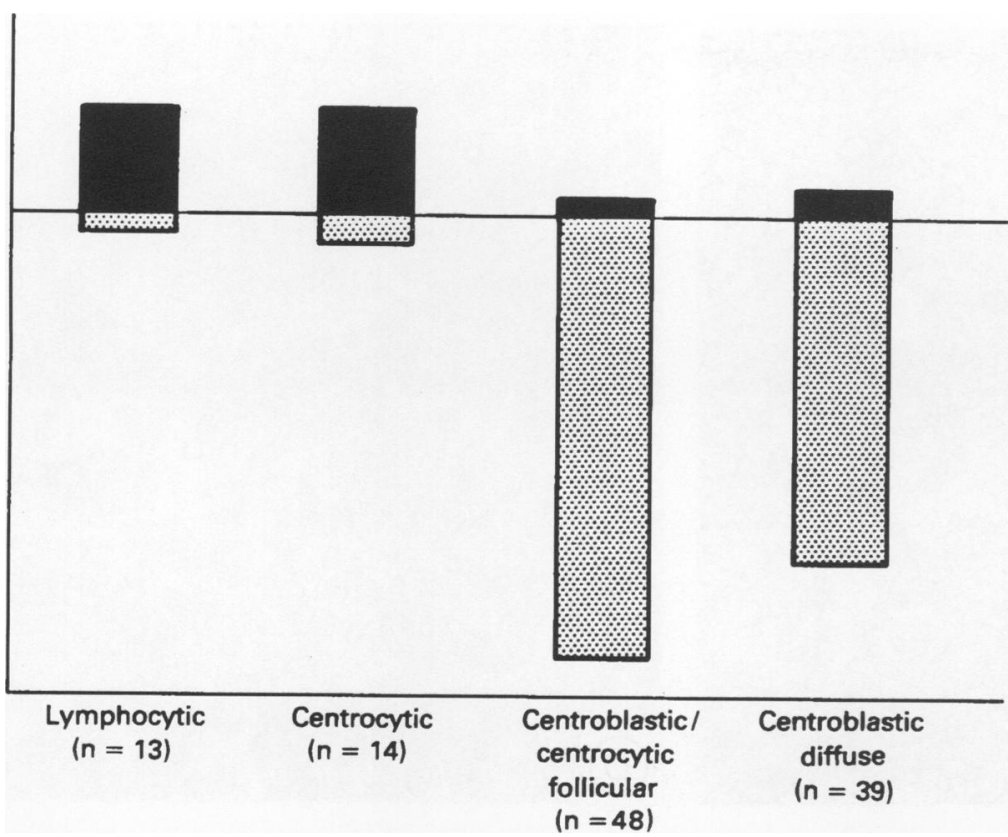

Figure 1 Histogram showing relative numbers of lymphomas which are CD43 positive (solid) and CD43 negative (shaded).

sections were available, were obtained from the files of Southampton General Hospital. Histological diagnosis, made according to the Kiel classification, was confirmed in routinely prepared sections without knowledge of the CD43 status. Frozen sections stained for a panel of monoclonal antibodies (table 1) were reviewed in all cases, and B cell lineage was confirmed by the use of CD37, CD19, and CD22. The results of staining for CD5 were available in 91 of the cases.

WR14 was raised following fusion of NS-O myeloma cells with splenocytes from a Balb/c mouse immunised with T-CLL cells. ${ }^{15}$

WR14 antibody, at a concentration of $5 \mathrm{mg} /$ $\mathrm{ml}$ in $0.1 \mathrm{M} \mathrm{NaHCO}$ (pH 8.5), was biotinylated by mixing with biotin (Sigma B2643) dissolved in DMSO at $25 \mathrm{mg} / \mathrm{ml}$, to give a ratio of $1 \mathrm{mg}$ biotin to $10 \mathrm{mg}$ antibody (10\%). After incubation at room temperature for four hours the reaction was stopped with $5 \mu$ l ethanolamine. Unwanted reactants were removed by extensive dialysis against PBS. ${ }^{16}$

Biotinylated WR14 was applied to sections of a formalin fixed reactive lymph node with or without prior application of the unlabelled CD43 monoclonal antibody MT1.5 The ability of MT1 to block WR14 binding was tested at a WR 14 concentration of $1 / 200$, a titre known to give good staining of lymphocytes in formalin

Table 2 Relation between CD43 and CDS

\begin{tabular}{llllll}
\hline & $\begin{array}{l}\text { Total cases in which } \\
C D 5 \text { available }\end{array}$ & $\begin{array}{l}\text { CD43+ } \\
C D 5+\end{array}$ & $\begin{array}{l}C D 43+ \\
C D 5-\end{array}$ & $\begin{array}{l}C D 43- \\
C D 5+\end{array}$ & $\begin{array}{l}\text { CD43- } \\
C D 5-\end{array}$ \\
\hline Lc & 8 & 6 & 2 & 0 & 0 \\
Cc & 7 & 5 & 2 & 0 & 0 \\
CbCcF & 36 & 0 & 0 & 0 & 36 \\
CbD & 25 & 0 & 2 & 3 & 20 \\
CbCcD & 4 & 0 & 0 & 0 & 4 \\
Cb FD & 3 & 0 & 2 & 0 & 1 \\
CbCcFD & 1 & 1 & 0 & 0 & 6 \\
MALT, LG & 7 & 0 & 0 & 1 & 67 \\
Total & 91 & 12 & 8 & 4 & \\
\hline
\end{tabular}

Significantly associated, $\chi^{2}=31.8 ; p<0.001$. fixed, paraffin wax embedded tissue, with blocking steps from $1 / 50$ to $1 / 400$.

\section{Results}

Directly biotinylated WR14 antibody gave strong positive staining in reactive lymph node at a range of concentrations. In the presence of the unlabelled CD43 reagent MT1, however, the activity of directly biotinylated WR14 was blocked, indicating that WR14 is a CD43 reagent which binds to an epitope identical with, or close to, that recognised by MT1.

CD43 expression was seen in 11 of 13 (84\%)Lc and 11 of 14 (78\%) Cc (fig 1) but in only $9 \%$ of the 95 FCC: CbCcF two of 48 , $\mathrm{CbD}$ three of $39, \mathrm{CbCcD}$ none out of four, CbFD two of three and CbCc FD one of one. The eight low grade MALT lymphomas were all CD43 negative. One high grade tumour, which had transformed from a low grade MALT lymphoma, showed strong CD43 staining of all cells.

There was a significant positive correlation between the expression of CD43 and CD5 ( $p$ $<0.001$ ) (table 2). In a few cases (13\%) CD5 and CD43 were not coexpressed.

\section{Discussion}

There have been few studies of paraffin wax processed material on the expression of CD43 on neoplastic B cells. The reported results vary considerably. In follicle centre cell lymphomas most authors have reported negative results with CD43 reagents, ${ }^{517-20}$ but positive staining has been reported in a small number of cases $^{4621} ; 15$ cases from our own files in which MT1 staining in paraffin wax was available were all negative, including one in which WR14 expression was shown in frozen tissue. In lymphocytic lymphomas weak positive staining has been observed in all cases $(n=7), 5$ or in only $50 \%(n=12)^{22}$; in three cases from our files two cases showed positive staining in some of the cells. All 12 cases of centrocytic lymphoma in Poppema's series ${ }^{5}$ showed weak positive staining, but three cases reported by Dobson $^{21}$ were negative, and 11 of 12 cases in this department were also negative in paraffin wax processed material, including two in which WR14 staining was positive in frozen sections. In view of the variable results obtained in paraffin wax studies this frozen section study of a large series of cases gives a useful baseline assessment of rates of CD43 expression.

Several authors have observed that CD43 antibodies reactive in formalin fixed, paraffin processed material, such as MT1, stain neoplastic B cells more weakly than the accompanying reactive $T$ lymphocytes ${ }^{4517}$ and thus the sensitivity of the antigen detection system and the conditions of fixation may be important limiting factors. ${ }^{23} \mathrm{Ng}$ et al reported that whereas all of $55 \mathrm{~T}$ cell lymphomas were positive in frozen sections, only $69 \%$ stained positively in paraffin processed material. ${ }^{7}$ They showed an inverse correlation between fixation time and positivity rate. Our study of overall 

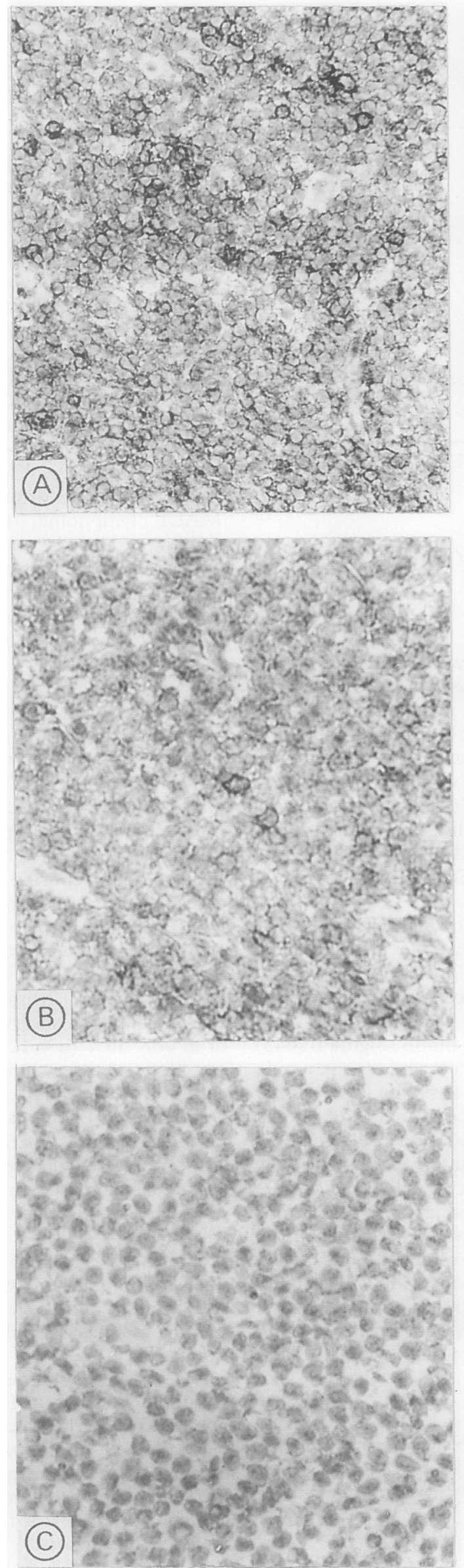
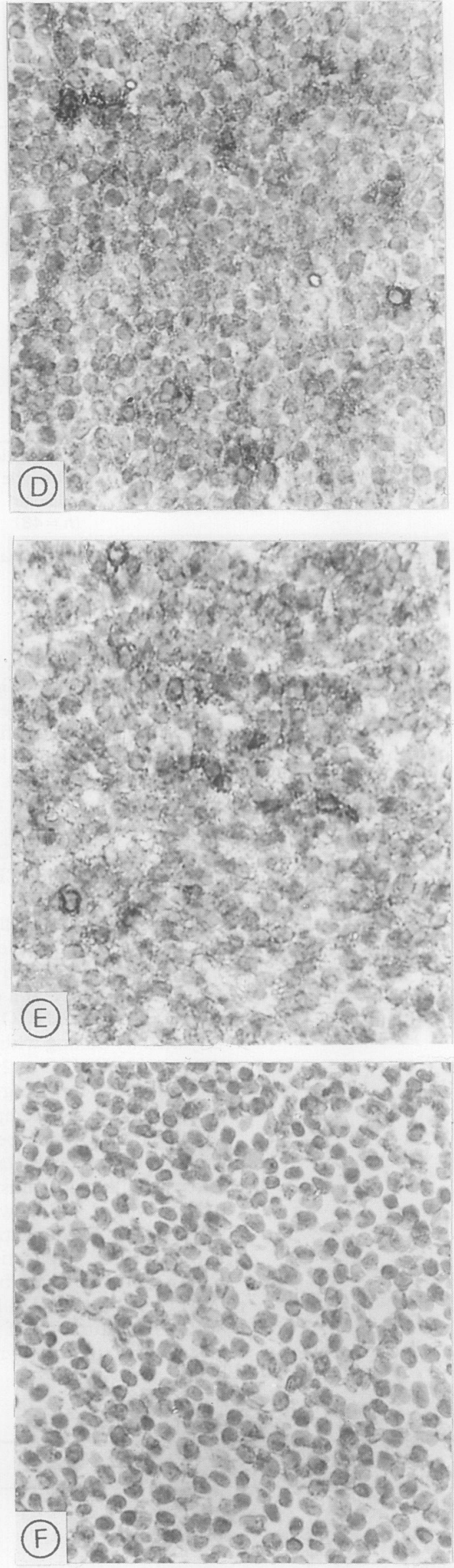

Figure 2 (A-C) Lymphocytic lymphoma showing expression of $C D 43(A)$ and $C D 5(B)$, but negative staining for $C D 10(C)$. Scattered reactive $T$ lymphocytes show stronger CD43 expression than positive tumour cells in $(A)$. (D-F) Centrocytic lymphoma, also positive for CD43 (D) and CD5 (E) but negative for CD10 (F). 

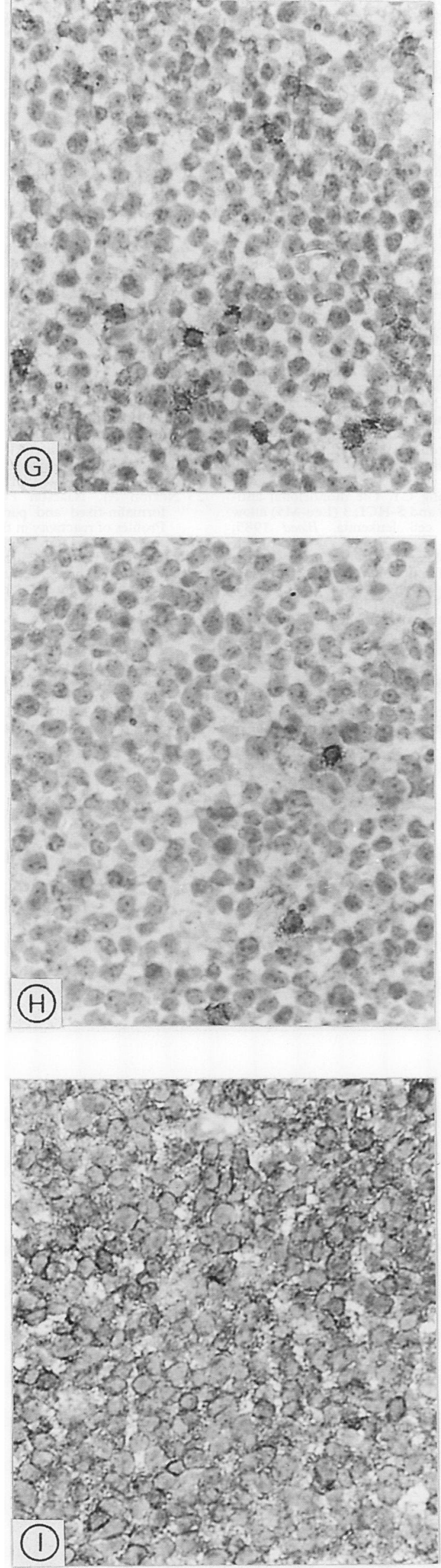

Figure 2 (G-I) Follicle centre cell lymphoma, negative for $C D 43$ (G) and CDS (H) but positive for $C D 10$ (I).
CD43 expression in frozen tissue avoided false negative results due to fixation effects.

The monoclonal antibody WR14 has been used in our diagnostic B cell frozen section panel for five years. Studies reported in the Fourth Leucocyte Typing Workshop, together with our confirmatory epitope blocking studies, indicate that WR14 has CD43 reactivity and it has therefore been possible to review the expression of CD43, as detected by WR14 frozen section immunostaining, in a large range of $B$ cell lymphomas.

The expression of CD43 by normal $T$ lymphocytes can occasionally cause difficulty in interpretation of staining results, particularly where a heavy reactive $T$ cell infiltrate is present. We were able to distinguish between CD43 positive reactive $T$ lymphocytes and neoplastic B lymphocytes, both on morphological grounds, and with the use of parallel CD3 staining.

We have shown that most lymphocytic and centrocytic lymphomas express CD43 (84\% and $78 \%$, respectively): most FCC lymphomas are CD43 negative (Fig 1). A slightly higher proportion of centroblastic diffuse lymphomas (three of 36) than $\mathrm{CbCcF}$ lymphomas (two of 46) gave positive results. This may be explained by the higher grade nature of these lesions, bearing in mind that CD43 may be expressed on the surface of $B$ cells following activation. $^{1}$

All eight low grade MALT lymphomas were CD43 negative. These tumours typically show absence of CD5 expression, ${ }^{24}$ and the absence of CD43 expression adds to the evidence that the centrocyte-like cells of MALT lymphoma are immunophenotypically distinct from the neoplastic cells of centrocytic lymphoma. The only positive tumour of MALT in our series was a high grade tumour showing the features of transformation.

Stross et al have previously described an association between CD43 and CD5 expression in a small series of paraffin wax processed, formalin fixed lymphocytic lymphoma and CLL, and in blood films from patients with CLL. ${ }^{4}$ Various authors have reported that CD5 is present on only a minority of follicle centre cell lymphomas. ${ }^{25-27}$ Our data, based on a large series of phenotypically defined tumours of the B cell series, confirm that the correlation between $\mathrm{CD} 5$ and $\mathrm{CD} 43$ is significant, and show that while either antigen can occasionally be found in isolation, the use of antibodies to both CD5 and CD43 in a diagnostic panel can provide valuable confirmatory information concerning B cell sublineage.

We gratefully acknowledge the help of the technical staff of the University Department of Pathology.

1 Stoll M, Dalchau R, Schmidt RE. Cluster report: CD43. In Knapp W, ed. Leucocyte Typing IV. Proceedings of the Fourth International Workshop and Conference on Human Leucocyte Differentiation Antigens. 1989 February 21-25; Vienna. New York: Oxford University Press, 1989:604-8.

2 Hadam MR, Othmer M. CD43 antibodies may be used for negative enrichment of B-cells. In: Knapp W, ed. Leuco cyte Typing IV. Proceedings of the Fourth International Workshop and Conference on Human Leucocyte Differ entiation Antigens. 1989 February 21-25; Vienna. New York: Oxford University Press, 1989: 612-4.

3 Axelsson B, Wike'n M, Vargas-Cortes M. Effect of CD43 
antibody B1-B6 on T-, B- and NK-cell function. In Knapp W, ed. Leucocyte Typing IV. Proceedings of the Fourth International Workshop and Conference on Human Leucocyte Differentiation Antigens. 1989 February 21-25; Vienna. New York: Oxford University Press, 1989: 617-9.

4 Stross WP, Warnke RA, Flavell DJ et al. Molecule detected in formalin fixed tissue by antibodies MT1, DF-T1, and L60 (Leu-22) corresponds to CD43 antigen. $\mathcal{F}$ Clin Pathol 1989;42:953-61.

5 Poppema S, Hollema H, Visser L, Vos H. Monoclonal antibodies (MT1, MT2, MB1, MB2, MB3) reactive with leukocyte subsets in paraffin-embedded tissue sections. Am ₹ Pathol 1987;127:418-29.

6 Picker LJ, Weiss LM, Medeiros LJ, et al. Immunophenotypic criteria for the diagnosis of non-Hodgkin's lymphoma. criteria for the diagnosis of non-
Am $\mathcal{F}$ Pathol 1987;128:181-201.

$7 \mathrm{Ng} \mathrm{CS}$, Chan JKC, Hui PK, Lo STH. Monoclonal antibodies reactive with normal and neoplastic $T$ cells in paraffin sections. Hum Pathol 1988;19:295-303.

8 Moore $\mathrm{K}$, Cooper SA, Jones DB. Use of the monoclonal antibody WR17, identifying the CD37 gp40-45 Kd antigen complex, in the diagnosis of B-lymphoid malignancy. F Pathol 1987;152:13-21.

9 Pezzuto A, Dorken A, Feller G, et al. HD37 monoclonal antibody: a useful reagent for further characterisation of "non-T, non-B" lymphoid malignancies. In: Reinherz EL, Haynes BF, Nadler LM, Bernstein ID, ed. Leukocyte Typing II. Proceedings of the Second International Workshop on Human Leukocyte Differentiation Antigens. 1984 on Human Leukocyte Differentiation Antigens. 1984
September 17-20; Boston. Volume 2. Human Blymphocytes. New York: Springer Verlag, 1986: lymphocytes.

10 Schwarting $R$, Stein H, Wang CY. The monoclonal antibodies S-HCL 1 (Leu-14) and S-HCL 3 (Leu-M5) allow the diagnosis of hairy cell leukemia. Blood 1985; 65:974-83.

11 Reinherz EL, Kung PC, Goldstein G, et al. Discrete stages of human intrathymic differentiation: analysis of normal thymocytes and leukemic lymphoblasts of T-cell lineage. Proc Natl Acad Sci USA 1980;b77:1588-92.

12 Lueders AM, Feller AC. Immunohistochemical investigations with B-cell Leucocyte Typing III. Proceedings of the Third International Workshop on Human Leucocyte Differentiation Antigens. 1986 September 21-26; Oxford. Oxtiation Antigens. Oxford University Press, 1987:462-5.

$13 \mathrm{Hogg}$ N; Ross GD, Jones DB, et al. Identification of an antimonocyte monoclonal antibody that is specific for membrane complement receptor type one $\left(C_{1}\right)$. Eur $\mathcal{f}$ Immunol 1984;14:236-43.
14 Beverley PCL, Callard RE. Distinctive functional characteristics of human "T" lymphocytes defined by $E$ rosetting or a monoclonal anti-T cell antibody. Eur $\mathcal{f}$ Immuno 981;11:329-34.

15 Moore K, Nesbitt AM. Identification and isolation of OKT4+ suppressor cells with the monoclonal antibody WR16. Immunology 1986;58:659-64.

16 Hardy RR. Purification and coupling of fluorescent proteins for use in flow cytometry. In: Weir DM, ed. Handbook of Experimental Immunology. 4th ed. Oxford: Blackwell Scientific Publications, 1986.

17 Norton AJ, Isaacson PG. Detailed phenotypic analysis of B-cell lymphoma using a panel of antibodies reactive in B-cell lym fixed ung 1987;128:225-40.

18 Ngan B, Picker LJ, Medeiros LJ, Warnke RA. Immunophenotypic diagnosis of non-Hodgkin's lymphoma in paraffin notypic diagnosis of non-Hodgkin's lymphom

19 West KP, Warford A, Fray L, Allen M. The demonstration of B-cell, T-cell and myeloid antigens in paraffin sections. $\mathscr{J}$ Pathol 1986;150:89-101.

20 Hall PA, D'Ardenne AJ, Butler MG, et al. New marker of B lymphocytes, MB2: comparison with other lymphocyte subset markers active in conventionally processed tissue sections. $\mathcal{f}$ Clin Pathol 1987;40:151-6.

21 Dobson CM, Myskow MW, Krajewski AS, et al. Immunohistochemical staining of non-Hodgkin's lymphoma in parafin sections using the MB1 and MT1 monoclonal parafin sections using the $\mathrm{MB1}$ and

22 Hall PA, D'Ardenne AJ, Stansfeld AG. Paraffin section immuno Ardenne AJ, Stansfeld AG. Paraffin section immunohistochemistry. I. Non-

23 Norton AJ, Isaacson PG. Lymphoma phenotyping in formalin-fixed and paraffin wax-embedded tissues. II Profiles of reactivity in the various tumour types. Histopathology 1989;14:557-79.

24 Spencer J, Finn T, Pulford KAF, et al. The human gut contains a novel population of $\mathrm{B}$ lymphocytes which resemble marginal zone cells. Clin Exp Immunol 1985;62:607-12.

25 Burns BF, Warnke RA, Doggett RS, Rouse RV. Expression of a T-cell antigen (Leu-1) by B-cell lymphomas. $A m \mathcal{F}$ Pathol 1983;113:165-71.

26 Knowles DM, Halper JP, Azzo W, Wang CY. Reactivity of monoclonal antibodies Leu 1 and OKT1 with malignant human lymphoid cells. Cancer 1983;52:1369-77.

27 Harris NL Nadler LM, Bhan AK. Immunohistologic characterization of two malignant lymphomas of germinal center type (centroblastic/centrocytic and centrocytic) center type (centroblastic/centrocytic and centrocytic)
with monoclonal antibodies. Am $f$ Pathol 1984; 